\title{
Extracts of pine bark (Pinus sylvestris) inhibit Cryptosporidium parvum growth in cell culture
}

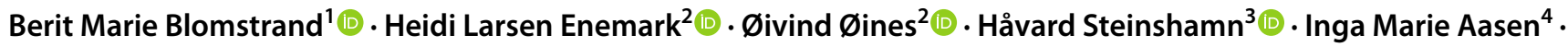 \\ Karl-Christian Mahnert ${ }^{5} \cdot$ Kristin Marie Sørheim $^{1} \cdot$ Spiridoula Athanasiadou $^{6}$ (D) Stig Milan Thamsborg ${ }^{7}$. \\ lan David Woolsey ${ }^{2}$ (I)
}

Received: 24 March 2021 / Accepted: 9 June 2021 / Published online: 16 July 2021

(c) The Author(s) 2021

\begin{abstract}
The widespread apicomplexan parasite Cryptosporidium parvum is responsible for severe gastrointestinal disease in humans and animals. The treatment options are limited, and the efficacy of available drugs is low. Bark contains condensed tannins (CT), which are bioactive compounds previously shown to inhibit parasite development. Here, we examined the anti-cryptosporidial properties of bark extract of Scots pine (Pinus sylvestris) against $C$. parvum by means of an in vitro growth inhibition test. We hypothesised that bark extracts would have dose-dependent inhibitory effects on the development of $C$. parvum in cell culture. Bark extracts from Scots pine extracted with acetone, methanol, and water as solvents were investigated using human colorectal adenocarcinoma cells infected with $C$. parvum. Oocysts were inoculated onto the cell monolayer and bark extract was added at seven different concentrations. Parasite growth inhibition was quantified by qPCR.

The acetone and methanol extracts demonstrated a sigmoid dose-dependent inhibition of $C$. parvum. The $\mathrm{IC}_{50}$ values were 244.6 and $279.1 \mu \mathrm{g}$ dry matter extract $/ \mathrm{mL}$, and 25.4 and $24.1 \mu \mathrm{g} \mathrm{CT} / \mathrm{mL}$, for acetone and methanol extracts, respectively. The $\mathrm{IC}_{50}$ for both extracts were similar, both with regard to the dry matter concentration of each extract and to CT concentrations. Given the limited treatment options available for Cryptosporidium spp., the evidence generated in our study encourages further investigation into the in vitro and in vivo effects of pine bark extracts against $C$. parvum.
\end{abstract}

Keywords Cryptosporidium parvum $\cdot$ Pine bark $\cdot$ Condensed tannins

\section{Introduction}

Cryptosporidium parvum is an apicomplexan parasite with a worldwide distribution and a high zoonotic potential. Oocysts excreted in the faeces are immediately infective. Transmission is via the faecal-oral route, directly from host to host, or indirectly via the environment, by ingestion of

Section Editor: Sutherland Maciver

Ian David Woolsey

ian.woolsey@nmbu.no

1 Norwegian Centre for Organic Agriculture, Tingvoll, Norway

2 Department of Animal Health and Food Safety, Norwegian Veterinary Institute, Oslo, Norway

3 Division of Food Production and Society, Grassland and Livestock, Norwegian Institute of Bioeconomy Research, Tingvoll, Norway contaminated food or water (Kosek et al. 2001) or possibly via insect vectors (Graczyk et al. 2003). Globally, cryptosporidiosis is a significant cause of diarrhoeal disease in humans and animals, and $C$. parvum is one of the most frequently diagnosed agents, with possible fatal consequences in children and immunocompromised individuals (Innes et al. 2020). Cryptosporidium spp. may lead to chronic joint

4 SINTEF Industry, Biotechnology and Nanomedicine, Trondheim, Norway

5 The Norwegian Institute of Wood Technology, Oslo, Norway

6 Animal and Veterinary Sciences, Scotland's Rural College, Edinburgh, UK

7 Department of Veterinary and Animal Sciences, University of Copenhagen, Frederiksberg, Denmark 
pain, fatigue, and post-infectious irritable bowel syndrome in humans (Carter et al. 2019). Similarly, C. parvum causes diarrhoea, loss of condition, and reduced growth rate in new-born calves, lambs, and other vertebrates (Smith 2008). Cryptosporidiosis in Norway is generally believed to be underdiagnosed (Nygård et al. 2003). A survey between 2001 and 2003 demonstrated C. parvum infection in 53\% of the dairy farms included in the study $(n=136)$ (Hamnes et al. 2006a), and a study on wild cervids completed in the same time period concluded that $C$. parvum is widespread among the cervid population in Norway (Hamnes et al. 2006b). An outbreak of human cryptosporidiosis in Norway was first reported in 2006 and was related to contamination from calves (Robertson et al. 2006). In 2011 and 2014, two additional animal associated human outbreaks were reported (Rimšelienè et al. 2011; Lange et al. 2014).

The options for treatment and prevention of cryptosporidiosis in both animals and humans are limited and, in many cases, suboptimal. Presently, there are to our knowledge only two moderately effective pharmaceuticals applied for metaphylactic treatment of calves: halofuginone lactate and paromomycin (The European Commission 2020; US food and drug administration 2020). Nitazoxanide is the only licenced pharmaceutical for use in humans, and the drug has limited effect in immunocompromised patients. Currently, there are no vaccines against $C$. parvum, and the robust oocysts are highly resistant to the most commonly used disinfectants (Innes et al. 2020).

There is evidence that dietary plant secondary metabolites (PSM) possess antiparasitic properties, both in vitro and in vivo (Anthony et al. 2005; Hoste et al. 2015). For instance, condensed tannins (CT) have proven antiparasitic effects (Dhakal et al. 2015; Desrues et al. 2016b; Spiegler et al. 2017). Few studies have tested the activity of different PSM against $C$. parvum (Sreter et al. 1999; Shahiduzzaman et al. 2009; Teichmann et al. 2012, 2016; Gaur et al. 2018; Woolsey et al. 2019b), and even fewer have tested CTs against C. parvum in animals (Kim and Healey 2001; Derbakova et al. 2016). To our knowledge, bark extracts from pine (Pinus sylvestris) have not previously been tested systematically against $C$. parvum in cell cultures in vitro.

The current insufficient treatment options against cryptosporidiosis and the possibility to exploit large amounts of excess bark from the Norwegian forest industry offer a strong incentive to further explore novel approaches to control cryptosporidiosis including bioactive compounds from bark extracts. In this study, we assessed the anti-cryptosporidial properties of bark extract of Scots pine against $C$. parvum by means of an in vitro growth inhibition test (Slifko et al. 1997; Woolsey et al. 2019a). We hypothesised that bark extracts with high CT concentration would have dosedependent inhibitory effects on the intracellular development of $C$. parvum in cell culture.

\section{Materials and methods}

\section{Parasite material}

Cryptosporidium parvum oocysts (Iowa strain) purchased from Bunch Grass Farm (ID, USA) harvested from suckling calves and isolated by sucrose gradient centrifugation within 14 days prior to delivery to the institute were stored at $2 \times 10^{7}$ oocysts/mL in $50 \mathrm{~mL}$ phosphate-buffered saline (PBS) with penicillin $1000 \mathrm{IU}$ and streptomycin $1000 \mu \mathrm{g}\left(2-7^{\circ} \mathrm{C}\right)$. The viability of the oocysts was assessed within a week before the assays by staining oocysts in wet mounts with 4',6-diamidino2-phenylindole (DAPI) and propidium iodide (PI) (Campbell et al. 1992; Petersen and Enemark 2018). The oocysts ( $\geq 100)$ were counted using immunofluorescence microscopy, and the viability percentage was calculated $(90 \%)$. This percentage was taken into account when calculating the concentration of viable oocyst in the stock solution.

The oocyst concentration was assessed within a week prior to the trial by diluting $10 \mu \mathrm{L}$ stock solution with $990 \mu \mathrm{L}$ PBS. Subsequently, 10 samples of $5 \mu \mathrm{L}$ diluted stock solution were stained with Crypt-a-Glo (Waterborne Inc, LA, USA) according to the product instructions and counted using an immunofluorescence microscope fitted with a fluorescein isothiocyanate (FITC) filter.

\section{Cell culture}

Human ileocecal colorectal adenocarcinoma (HCT-8) cells (ECACC, Salisbury, UK) (Upton et al. 1994; Joachim et al. 2018) were maintained as described by Woolsey et al. (2019a). A cell subcultivation was performed twice a week, when $80 \%$ confluent, using trypsin/EDTA (Sigma Aldrich, MO, USA). The cell cultures were incubated at $37{ }^{\circ} \mathrm{C}, 5 \% \mathrm{CO}_{2}$ and $100 \%$ humidity. HCT- 8 cells $\left(2 \times 10^{5}\right.$ per well) were seeded onto Nunclon® 96-well plates (Sigma Aldrich, MO, USA) and incubated till $80 \%$ confluence $(24 \mathrm{~h})$.

\section{Bark extraction and determination of the concentration of condensed tannins (CT)}

Bark from $P$. sylvestris was ring debarked and collected in a sawmill in eastern Norway (Bergene Holm AS, Kirkenær) in March 2017 and stored at $-20{ }^{\circ} \mathrm{C}$ until use. The bark was milled to chips of $0.5-2 \mathrm{~cm}$ in a hammer mill (Schutte Mini Mill, Buffalo, NY, USA), freeze-dried, and ground to particle sizes of approximately $2 \mathrm{~mm}$ in a coffee grinder. Aqueous acetone $(70 \%)$, aqueous methanol $(80 \%)$, and water were used as solvents producing three different extracts, PS-Ac, PS-Me, and PS-H2O, respectively. PS-Ac and PS-Me were prepared by adding $200 \mathrm{~mL}$ solvent to $10 \mathrm{~g}$ fine-ground 
bark, in an ultrasonic cleaning bath at full power $(60 \mathrm{~W})$ for $20 \mathrm{~min}$ (temperature increasing from 20 to $30^{\circ} \mathrm{C}$ ). For PS$\mathrm{H} 2 \mathrm{O}, 100 \mathrm{ml}$ water was added to $10 \mathrm{~g}$ fine-ground bark, the extract was separated, and the procedure repeated. The temperature was $65^{\circ} \mathrm{C}$, and the time was $1 \mathrm{~h}$ for each of the two steps. The extracts were isolated by centrifugation and filtration (Whatman no 1) using vacuum suction. The organic solvents (acetone or methanol) were removed by evaporation (Rotavapor, $38^{\circ} \mathrm{C}$ ) before freezing and freeze-drying. For PS-H2O, the combined extracts were concentrated in a vacuum centrifuge at $65{ }^{\circ} \mathrm{C}$ (Thermo Scientific Savant SC250EXP SpeedVac Concentrator) to approximately 50\% of the volumes, before freezing and freeze-drying. The dried extracts were stored at $-20^{\circ} \mathrm{C}$ until further use.

Total CTs were quantified by the butanol- $\mathrm{HCl}$ assay. Freeze-dried extracts were dissolved in methanol $(80 \%$ in water) and analysed with cyanidin- $\mathrm{HCl}$ as standard (Grabber et al. 2013), using the conventional reagent without acetone, $2.5 \mathrm{~h}$, and absorbance reading at $545 \mathrm{~nm}$.

To determine the relative monomer composition, the mean degree of polymerisation (mDP), and cis-trans-ratio, the methanol extracts were thiolysed with cysteamine hydrochloride and analysed by HPLC (Bianchi et al. 2015) using an Ascentis Express C18 column $(15 \mathrm{~cm} \times 2.1 \mathrm{~mm}, 2.7 \mu \mathrm{m}$, Supelco) and a flow rate of $0.3 \mathrm{~mL} / \mathrm{min}$.

Immediately prior to use, the dried extracts were dissolved in $100 \%$ dimethyl sulfoxide (DMSO), vortexed $>1 \mathrm{~min}$, and diluted down to final extract concentrations of $300 \mu \mathrm{g} / \mathrm{mL}, 250 \mu \mathrm{g} / \mathrm{mL}, 200 \mu \mathrm{g} / \mathrm{mL}, 150 \mu \mathrm{g} / \mathrm{mL}$, $100 \mu \mathrm{g} / \mathrm{mL}$, and $50 \mu \mathrm{g} / \mathrm{mL}$ dry matter extract in $1 \%$ DMSO using maintenance medium (MM; RPMI-1640 (Biowest, France) supplemented with 5\% v/v bovine foetal serum, 5\% $\mathrm{v} / \mathrm{v}$ horse serum, $1 \mathrm{mM}$ sodium pyruvate, penicillin $100 \mathrm{U} /$ $\mathrm{mL}$, streptomycin $100 \mu \mathrm{g} / \mathrm{mL}$, and amphotericin B $0.25 \mu \mathrm{g} /$ $\mathrm{mL}$ (all from Sigma Aldrich, MO, USA)).

\section{Parasite inoculation onto cell monolayer and addition of extract}

Before inoculation, the oocysts went through an excystation protocol as described earlier (Slifko et al. 1997; Woolsey et al. 2019a): $2 \times 10^{6}$ viable oocysts $(120 \mu \mathrm{L})$ and $2 \times 10^{6}$ inactivated oocyst $(\mathrm{IO})$ solution $(120 \mu \mathrm{L}$ stock solution previously incubated at $70{ }^{\circ} \mathrm{C}$ for $30 \mathrm{~min}$ ) were suspended in bleach (120 $\mu \mathrm{L} \mathrm{5.35 \%} \mathrm{sodium} \mathrm{hypochlorite} \mathrm{and} 960 \mu \mathrm{L}$ MilliQ water) for $10 \mathrm{~min}$ on ice, and then centrifuged at $4000 \times \mathrm{g}$ for $4 \mathrm{~min}$ at $4{ }^{\circ} \mathrm{C}$. The supernatant was aspirated, and $14 \mathrm{~mL}$ MilliQ water was added to each of the suspensions. The solutions were vortexed for $10 \mathrm{~s}$ and spun again $(4000 \times \mathrm{g}$, $4 \mathrm{~min}, 4^{\circ} \mathrm{C}$ ). The supernatant was aspirated down to $200 \mu \mathrm{L}$ and the oocysts were re-suspended in $9.8 \mathrm{~mL}$ pre-warmed MM $\left(37^{\circ} \mathrm{C}\right)$, which gave a final oocyst concentration of $2 \times 10^{5}$ oocysts per millilitre.
Oocyst solution $(100 \mu \mathrm{L})$ was added to each monolayer well with a multichannel pipette with IO and MM as controls $(n=3)$. The plates were incubated for $4 \mathrm{~h}\left(37{ }^{\circ} \mathrm{C}, 5 \% \mathrm{CO}_{2}\right.$, $100 \%$ humidity), subsequently the wells were washed $5 \mathrm{~min}$ with PBS, and bark extracts were added to the live oocyst wells at the extract concentrations as mentioned above (biological repeat, $n=3$ for each concentration). DMSO (1\%) in $\mathrm{MM}$ was added to the negative MM controls and the IO wells, and paromomycin $(500 \mu \mathrm{g} / \mathrm{mL})$ in MM was added as positive control $(n=3)$ (see supplementary material for a plate overview). Each plate was duplicated.

\section{Cell viability}

After 44 -h incubation $\left(37{ }^{\circ} \mathrm{C}, 5 \% \mathrm{CO}_{2}, 100 \%\right.$ humidity) (Slifko et al. 1997), the cell viability was determined using an integrated non-destructive water-soluble tetrazolium salt assay (WST-1 cell proliferation assay kit; Roche, Basel, Switzerland): MM was aspirated from the wells and $10-\mu \mathrm{L}$ WST-1 $10 \%$ working solution was added to each well. The plates were incubated for $>30 \mathrm{~min}$ and the optical density was read at $450 \mathrm{nM}\left(\mathrm{OD}_{450}\right)$. The plates were read every 15 min until all negative control wells had reached an $\mathrm{OD}_{450}$ value of $>1$. Monolayers were considered viable if OD values in the extract wells were $>75 \%$ of the negative controls (Teichmann et al. 2012).

\section{DNA extraction}

The wells were washed $(3 \times 5 \mathrm{~min})$ with $100 \mu \mathrm{L}$ PBS $\left(37^{\circ} \mathrm{C}\right)$, and $20 \mu \mathrm{L}$ proteinase $\mathrm{K}$ and $180 \mu \mathrm{L}$ ATL buffer (Qiagen, Hilden, Germany) were added to each well. Then, the plates were incubated $\left(56^{\circ} \mathrm{C}, 90 \mathrm{~min}\right)$ and the content of each well was aspirated into $1.5 \mathrm{~mL}$ Eppendorf tubes. DNA extraction was performed by means of QIAcube DNeasy ${ }^{\circledR}$ blood and tissue kit (Qiagen, Hilden, Germany) (tissues and rodent tails protocol, elution volume: $200 \mu \mathrm{L}$ ).

\section{qPCR assay}

The growth of $C$. parvum in the cell cultures was assessed by measuring the amount of $C$. parvum specific DNA. Quantitative polymerase chain reaction (qPCR) was performed using 18S primers (Morgan et al. 1997) (Cryp18S_Frt 5'-AGTGACAAGAAATAACAATACAGG and Cryp18S Rrt 5'-CCTGCTTTAAGCACTCTAATTTTC-3') with hydrolysis probe (Amann et al. 1990; Keegan et al. 2003) (Integrated DNA Technologies, Coralville, IA, USA). Quantitative PCR reactions were conducted in a total volume of $25 \mu \mathrm{L}$ containing $3 \mu \mathrm{L}$ of each forward and reverse primers, $0.6 \mu \mathrm{L}$ probe, $12.5 \mu \mathrm{L} 2 \times$ Brilliant III Fast Master Mix (Agilent Technologies, Santa Clara, CA, USA), $5.4 \mu \mathrm{L}$ $\mathrm{dH}_{2} \mathrm{O}$ (nuclease-free water, Integrated DNA Technologies, 
Coralville, IA, USA), and $0.5 \mu \mathrm{L}$ DNA template. Reactions were run on 96-well white-bottomed qPCR plates (Bio-Rad, Hercules, CA, USA).

From each biological replicate plate, extracted DNA from each biological repeat $(n=3)$ was run in duplicate (2 technical repeats) on the qPCR plate. DNA template from a separate oocyst titration study (cell monolayer infected with $5 \times 10^{4}-50$ oocysts/well, 2 biological and 2 technical repeats per biological repeat per concentration) was added to each qPCR run to serve as DNA standards (Woolsey et al. 2019a).

The cycling conditions were initially $95^{\circ} \mathrm{C}$ for $2 \mathrm{~min}$ followed by 44 cycles $\left(95^{\circ} \mathrm{C}\right.$ for $10 \mathrm{~s}, 58^{\circ} \mathrm{C}$ for $10 \mathrm{~s}, 72^{\circ} \mathrm{C}$ for 20 s) on C1000 Touch (BioRad, Hercules, CA, USA). The definition of the cycle threshold was set at the beginning of the rise of the log-linear phase, and a quantification cycle (Cq) above 40 cycles was defined as negative based on the non-template controls included on each qPCR plate (Bustin et al. 2009). To analyse the amplification curves, BioRad CFX manager v3.1 software was used and the Cq values from the standard templates with known oocyst number were used to calculate the DNA level of the test templates. The data used in the subsequent analyses were defined as $C$. parvum DNA quantity relative to the DNA standard templates $\left(\mathrm{DNA}_{\text {rel }}\right)$.

\section{Statistics}

qPCR standard curves were produced in BIORAD CFX Manager v3.1. For each extract (PS-Ac, PS-Me, and PS$\mathrm{H} 2 \mathrm{O}$ ), data used for statistical analyses was collected from two independent parasite growth inhibition assays with three biological repeats per extract concentration and two technical repeats per well per assay. By plotting the seven extract concentrations as independent variables and $\mathrm{DNA}_{\text {rel }}$ as dependent variable, it appeared that the relationship was inverse sigmoid for PS-Ac and PS-Me. We therefore analysed the data using a non-linear regression procedure (NLIN) in SAS (SAS release 9.4, SAS Institute, Cary, NC), and applied this to calculate the half maximal inhibitory concentration $\left(\mathrm{IC}_{50}\right)$ for both PS-Ac and PS-Me. Two-sided $p$ values of $\leq 0.05$ were considered significant. The results from the PS-H2O assay were plotted into a simple (x,y)-plot and fitted a linear regression model.

\section{Results}

\section{Characterisation of bark extracts}

The extract DM yield per gram bark was 55, 47, and $54 \mathrm{mg} / \mathrm{g}$ for PS-Ac, PS-Me, and PS-H2O, respectively. The mean CT concentrations of PS-Ac, PS-Me, and PS-H2O were $95.3 \pm 3.0,90.9 \pm 2.2$, and $33.3 \pm 2.5 \mathrm{mg} / \mathrm{g} \mathrm{DM}$ extract ( \pm s.d.) $(9.5,9.1$, and $3.3 \%)$, respectively. The final CT concentrations in the dilutions thus ranged from 4.8 to 28.6, 4.5 to 27.3 , and 1.7 to $10.0 \mu \mathrm{g} / \mathrm{mL}$ in PS-Ac, PS-Me, and PS-H2O, respectively. For the methanol extract, the PC:PD ratio was > 99:1, cis:trans ratio 79:21, and mDP 5.8.

\section{Cell viability}

HCT-8 monolayer viability was within threshold limits of $75 \%$ of the negative controls in all wells on all plates except for two wells (yielding 70.0 and $73.8 \%$ of the negative controls), which were excluded from the later calculations.

\section{C. parvum growth inhibition assay}

Based on model property and the result of the statistical analysis (model mean square error and the value of the parameter estimates relative to their respective standard error), the following model (Model 1) was chosen for the extracts PS-Ac and PS-Me when testing the extract dry matter (DM) concentrations for anti-cryptosporidial effect $(p<0.01)$ :

$\mu_{y}(x)=\frac{\gamma}{1+\left(\frac{x}{\delta}\right)^{\theta}}$

$\mu_{y}(x)$ is the $\mathrm{DNA}_{\text {rel }}$ of a given value $x, x$ is the extract DM concentration, $\gamma$ is the value of $\mu_{y}(x)$ when no extract is applied $(x=0), \delta$ is the $x$ value at the inflection point (concentration of the strongest decline in $\mathrm{DNA}_{\text {rel }}$ ), which is equivalent to $\mathrm{IC}_{50}$, and $\theta$ describes the slope of the curve, i.e., the reduction in DNA $_{\text {rel }}$ per unit increase in extract (Table 1). Based on the calculation, we found a dose-dependent relationship between the extract DM concentration (PS-Ac and

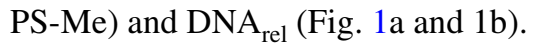

We used the same principles to investigate the relationship between CT concentration and $\mathrm{DNA}_{\text {rel }}$. Data from PS-Me (CT) converged using Model 1, and its estimated parameters are presented in Table 1 . The data from PS-Ac (CT) converged when using the following Model 2 $(p<0.0001)$ :

$E(y)=\alpha \cdot e^{-\beta \cdot e^{k \cdot x}}$.

$E(y)$ is the oocyst concentration of a given value $x, x$ is the extract CT concentration, $\alpha$ and $\beta$ describe the $\mathrm{DNA}_{\text {rel }}$ when no extract was applied $(x=0)$, and $\beta$ and $k$ form the slope of the curve. Table 2 lists the estimated parameters for the PS-Ac CT curve.

The $\mathrm{IC}_{50}$ for PS-Ac and PS-Me extracts were estimated to 244.6 and $279.1 \mu \mathrm{g} \mathrm{DM} / \mathrm{mL}$ (24.1 and $25.4 \mu \mathrm{g} \mathrm{CT} / \mathrm{mL}$ ), respectively. 
Table 1 Parameter estimates describing inhibition related to dry matter (DM) and CT concentrations

\begin{tabular}{|c|c|c|c|c|}
\hline \multirow[t]{2}{*}{ Parameter } & \multicolumn{2}{|l|}{ Extract (DM) } & \multirow{2}{*}{$\begin{array}{l}\text { Extract (CT) } \\
\text { PS-Me }\end{array}$} & \multirow{2}{*}{$\begin{array}{l}\text { Extract }(\mathrm{CT}) \\
\text { PS-CT }_{\mathrm{m}}\end{array}$} \\
\hline & PS-Ac & PS-Me & & \\
\hline Model $p$ value & $<0.0001$ & $<0.0001$ & $<0.0001$ & $<0.0001$ \\
\hline$\gamma$ & $24,125.4(1926.5)$ & $20,103.8(2755.8)$ & $20,103.8(2755.8)$ & $21,632.5$ (1448.6) \\
\hline$\delta\left(\mathrm{IC}_{50}\right)(\mu \mathrm{g} / \mathrm{mL})$ & 244.6 & 279.1 & 25.4 & 26.2 \\
\hline$\theta$ & $5.2594(2.3817)$ & $14.6109(15.1513)$ & $14.611(15.1514)$ & $11.2822(8.015)$ \\
\hline
\end{tabular}

For PS-Ac, DNA $\mathrm{Drl}_{\text {rel }}$ values were not significantly different from the positive control for concentrations higher than $200 \mu \mathrm{g} / \mathrm{mL}(P>0.05)$. For PS-Me, this was observed in concentrations above $250 \mu \mathrm{g} / \mathrm{mL}(P>0.05)$.

The results from the PS-H2O assay could not be fitted in any reasonable way by any of the sigmoid models we tried. A simple (x,y) plot of the observed data together with a fitted linear model shows no statistically significant relationship

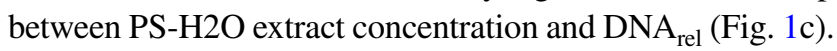

The CT data from all three extracts were merged (PS$\mathrm{CT}_{\mathrm{m}}$ ) and the relationship between PS-CT $\mathrm{T}_{\mathrm{m}}$ and $\mathrm{DNA}_{\text {rel }}$ was estimated with extract as random variable. The data converged using Model 1, and estimated parameters can be seen in Table 1. We found a dose-dependent negative correlation between the PS-CT $\mathrm{m}_{\mathrm{m}}$ concentration and $\mathrm{DNA}_{\text {rel }}$ (Fig. 1d). The $\mathrm{IC}_{50}$ for $\mathrm{PS}^{-\mathrm{CT}_{\mathrm{m}}}$ was estimated to $26.2 \mu \mathrm{g} \mathrm{CT} / \mathrm{mL}$.

\section{Discussion}

This study revealed a dose-dependent anti-cryptosporidial effect of acetone and methanol bark extracts (PS-Ac and PS-Me) from P. sylvestris. Our findings support the results of other studies addressing the possible effects of pine extracts against protozoa. Kim and Healey (2001) demonstrated in vivo that ethanol extracted bark extracts from Pinus pinaster reduced the oocyst shedding and improved the overall health of mice infected with $C$. parvum. Similarly, a study of goats infected with Eimeria spp. demonstrated that feeding pine (Pinus densiflora) needles significantly reduced the oocyst excretion compared to untreated controls. In the treated goats, oocyst excretion 10 days post-treatment was reduced by $93 \%$, relative to the pre-treatment oocyst excretion (Hur et al. 2005). In vitro antiprotozoal effect of bark extract has also been shown against Eimeria spp. of poultry, where water extracted pine bark reduced the oocyst sporulation by $77.2-86.4 \%$ relative to untreated controls (Molan et al. 2009).

Importantly, we showed that both PS-Ac and PS-Me were, in the highest concentrations, no different from their respective positive controls. This shows that the extracts have an in vitro anti-cryptosporidial effect close to that of paromomycin, one of the few pharmaceuticals registered for use in animals.

Furthermore, merging results of PS-Ac and PS-Me, we described a dose-dependent relationship between CT concentration and $\mathrm{DNA}_{\text {rel }}$. Previous evidence is not conclusive on whether the CTs in the plant extracts are the compounds responsible for their antiparasitic activity. In some cases, the observed activity is closely linked to CT concentration (Novobilsky et al. 2011, 2013; Desrues et al. 2016a), while others have been unable to demonstrate such a link (Castañeda-Ramírez et al. 2017; Hernández-Bolio et al. 2018; Esteban-Ballesteros et al. 2019). Possible explanations to this divergence include the degree of purity of the extracts, and it is evident that bioactivity of CTs is strongly related to chemical structure, e.g., type of monomers, $\mathrm{mDP}$ and degree of galloylation (Mueller-Harvey et al. 2019).

In this trial, the extracts with the highest CT concentration also demonstrated the highest antiprotozoal effect; thus, it is likely that CTs play an important role in the interaction between parasites and extracts. Nevertheless, the possibility that other PSM, such as other polyphenols or non-phenolic compounds like sesquiterpene lactones, may also have a role in the activity observed in this study cannot be excluded as previously suggested (Barone et al. 2019).

In our study, PS-Ac exhibited anti-cryptosporidial effect at a lower dose but had a lower rate of reduction compared to PS-Me (cf. $\theta$, Table 1). Additionally, the $\mathrm{IC}_{50}$ was lower for PS-Ac than for PS-Me. The CT concentration of both extracts was similar and showed approximately the same inhibition of the parasitic development. Yet, it was not possible to fit the data generated from both extracts to the same model. This may support the theory that unknown, non-CT components present had a clear influence on the anti-cryptosporidial effect and/or that differences in chemical composition were related to the extraction method.

To our knowledge, $\mathrm{IC}_{50}$ values for pine bark extracts tested against $C$. parvum have not been calculated before. Our findings were in accordance with Williams et al. (2014) who tested purified and fractionated acetone pine bark extracts against Haemonchus contortus in a larval migration 
Fig. 1 Inhibition of Cryptosporidium parvum development (black line) with increasing dry matter $(\mathrm{DM})(\mathbf{a}-\mathbf{c})$ or condensed tannins (CT) (d) concentrations from acetone (a), methanol (b), and water (c) based bark extracts from Scots pine (Pinus sylvestris). Black circles, mean DNA content relative to the standards $\left(\mathrm{DNA}_{\mathrm{rel}}\right)$ of observed values for each extract dose. Square, positive control (paromomycin). Triangle, half maximal inhibitory concentration $\left(\mathrm{IC}_{50}\right)$. Error bars on observed values represent standard error of the mean (SEM). Area between dashed lines: 95\% confidence interval. (d) DM concentrations was converted to $\mathrm{CT}$ concentrations, and all extracts were merged (PS-CT $\mathrm{m}_{\mathrm{m}}$ ). $\mathrm{PS}_{-} \mathrm{CT}_{\mathrm{m}}$ exhibited a negative correlation with $\mathrm{DNA}_{\text {rel. }}$. The symbols are mean of observed values of PS-Ac (squares), PS-Me (routes), and PS-H2O (black circles). The open circle displays the mean of the negative controls and the triangle the positive control

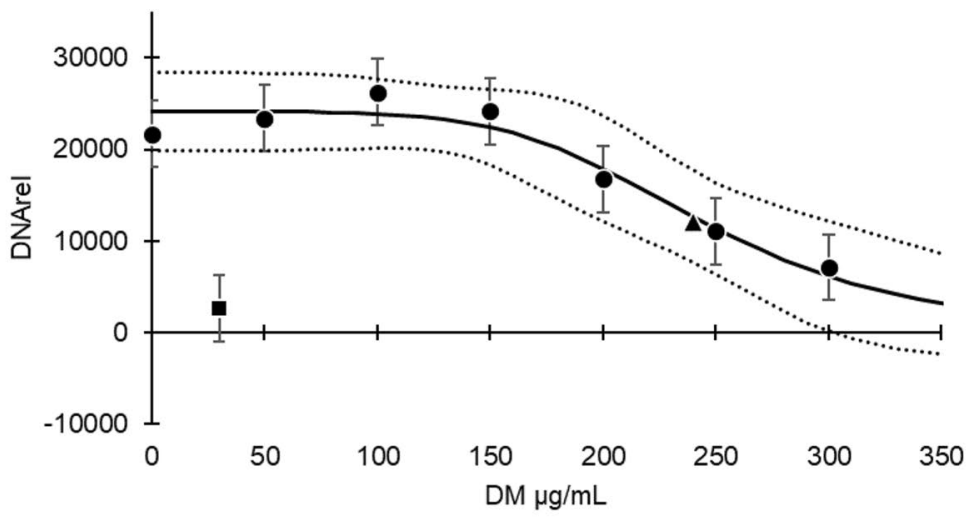

b
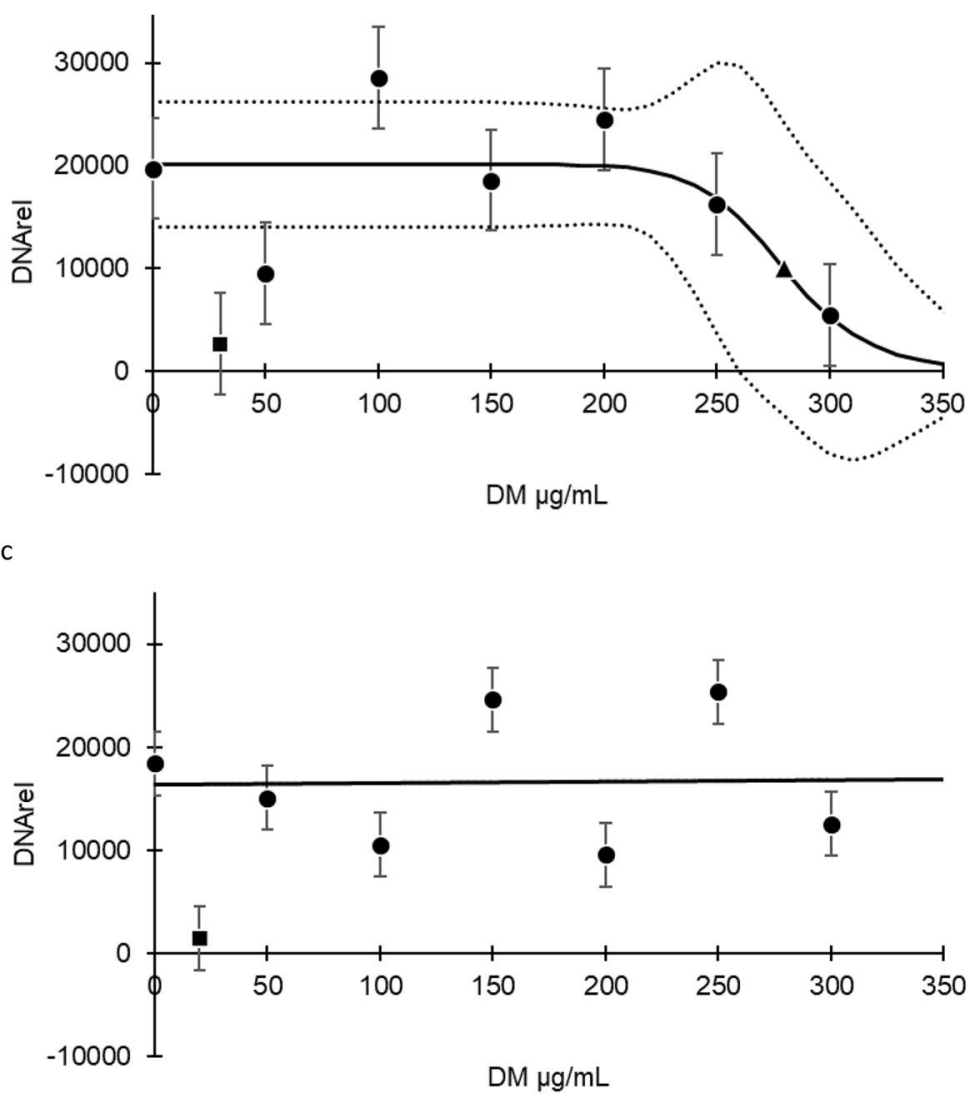

d

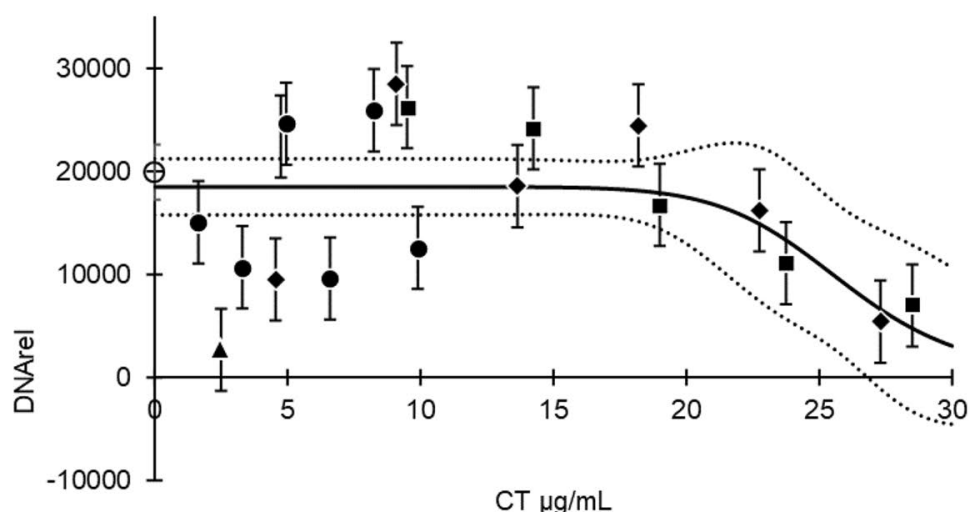


Table 2 Parameter estimates describing inhibition related to CT concentration for PS-Ac

\begin{tabular}{ll}
\hline Parameter & $\begin{array}{l}\text { Extract }(\mathrm{CT}) \\
\text { PS-Ac }\end{array}$ \\
\hline Model $p$ value & $<0.0001$ \\
$\alpha$ & $24,674.7(2828.3)$ \\
$\beta$ & $0.0114(0.026)$ \\
$k$ & $0.1713(0.0865)$ \\
$\mathrm{IC}_{50}(\mu \mathrm{g} / \mathrm{mL})$ & 24.1 \\
\hline
\end{tabular}

Data converged when using the function $\mu_{y}(x)=\alpha \cdot e^{-\beta \cdot e^{k \cdot x}}$, where $x$ is the CT concentration; $\alpha$ and $\beta$ give the oocyst level when $x=0$; and $\beta$ and $k$ describe the slope of the curve. $\mathrm{IC}_{50}$ is the half maximal inhibitory concentration for each extract

inhibition test and estimated $\mathrm{IC}_{50}$ to be $40.4 \mu \mathrm{g} \mathrm{CT} / \mathrm{mL}$. Molan (2014) found $\mathrm{IC}_{50}$ values of $69 \mu \mathrm{g} \mathrm{CT} / \mathrm{mL}$ in a Trichostrongylus colubriformis larval development inhibition assay with purified acetone pine bark extracts containing $35 \%$ CT. It has previously been shown that a high $\mathrm{mDP}$ and low PC:PD ratio are of importance when it comes to the antiparasitic activity (Mueller-Harvey et al. 2019). PS-Ac and PS-Me had a low CT percentage, low mDP, and negligible amount of PDs, which was generally in accordance with previous studies (Matthews et al. 1997; Bianchi et al. 2015, 2019; Desrues et al. 2016a), yet the anti-cryptosporidial effect was significant with a low $\mathrm{IC}_{50}$. This supports the assumption that other components may have contributed to the inhibition of the development of $C$. parvum.

For PS-H2O, there was no statistically significant relationship between the extract DM concentration and $\mathrm{DNA}_{\text {rel }}$ (Fig. 1c). Barone et al. (2019), on the other hand, tested 51 Lotus corniculatus water extracts in vitro and found dosedependent anthelmintic activity in several extracts, demonstrating that the use of water as a solvent does not preclude the extraction of active antiparasitic compounds. The lack of biological activity can be explained by the fact that we were not able to achieve a high enough concentration (DM or CT) or that the active components cannot be extracted using water as solvent.

Our results confirmed that acetone and methanol solvents have a higher ability to extract proanthocyanidins (CTs) from pine bark compared to water. This solvent-dependent difference in CT extractability is in accordance with Ramos et al. (2013), who found that water extracted bark extract from $P$. sylvestris had a high extract yield but a low concentration of total phenol and CT compared to extracts produced with methanol and acetone as solvents (Ramos et al. 2013). A possible reason for the low CT yield when using water as solvent is explained by Matthews et al. (1997) who describe direct linkages between non-extractable CTs and the cell wall matrix and weaker CT-CT linkages extractable with aqueous methanol but not with water. Despite the lack of anti-cryptosporidial effect of PS-H2O at the concentrations tested, it is important not to dismiss water extracts as inactive. Acetone and methanol are strictly regulated (Klima- og miljødepartementet 2004), highly flammable, toxic organic solvents potentially harmful to humans. Large scale production of bark extracts with the use of organic solvents is costly, and potential production sites are hard to come by. Water, on the other hand, is non-toxic to living organisms, leaves a lower environmental footprint and is less costly and easier to use for large scale production of extracts. We recommend further in vitro studies to test pine water extracts against $C$. parvum in higher concentrations.

Cryptosporidiosis is considered a neglected disease and reducing oocyst shedding in animals is an important One Health goal as it reduces the risk of disease in humans (Innes et al. 2020). If pine bark extracts can be used to combat livestock cryptosporidiosis, they may be an environmentally friendly alternative to the current pharmaceuticals and constitute a step towards minimising contamination of drinking water and subsequent human cryptosporidiosis.

\section{Conclusion}

Both acetone and methanol extracts of $P$. sylvestris showed marked anti-cryptosporidial properties by inhibiting the development of $C$. parvum in HCT- 8 cell cultures. The effect of the bark extracts was dose-dependent with $\mathrm{IC}_{50}$ values for $\mathrm{CT}$ almost similar between extracts (approximately $25 \mu \mathrm{g}$ $\mathrm{CT} / \mathrm{mL}$ ). At the highest concentrations, the inhibitory activities were similar to that of existing drugs. A dose-dependent effect could not be confirmed for the water extract. Ultimately, in vitro testing should be followed by in vivo experiments with pine bark extracts to assess their applicability and relevance for disease control in animals. We also suggest further exploration of the anti-cryptosporidial effect of water extracts.

\section{Data and materials availability}

The datasets generated during the current study are available from the corresponding author on reasonable request.

Supplementary Information The online version contains supplementary material available at https://doi.org/10.1007/s00436-021-07220-w.

Acknowledgements We thank the Research Council of Norway and the BIONÆR programme for funding this trial through the BarkCure project (Grant number 268264). We would also like to thank Inger Heffernan for her invaluable help in the laboratory and Dr Sokratis Ptochos for important support. 
Funding Open access funding provided by Norwegian University of Life Sciences. The project was funded by the Norwegian Research Council, funding number 268264. Scotland's Rural College (SRUC) receives funding from the Scottish government.

\section{Declarations}

Conflicts of interest The authors declare no competing interests.

Open Access This article is licensed under a Creative Commons Attribution 4.0 International License, which permits use, sharing, adaptation, distribution and reproduction in any medium or format, as long as you give appropriate credit to the original author(s) and the source, provide a link to the Creative Commons licence, and indicate if changes were made. The images or other third party material in this article are included in the article's Creative Commons licence, unless indicated otherwise in a credit line to the material. If material is not included in the article's Creative Commons licence and your intended use is not permitted by statutory regulation or exceeds the permitted use, you will need to obtain permission directly from the copyright holder. To view a copy of this licence, visit http://creativecommons.org/licenses/by/4.0/.

\section{References}

Amann RI, Binder BJ, Olson RJ et al (1990) Combination of $16 \mathrm{~S}$ rRNA-targeted oligonucleotide probes with flow cytometry for analyzing mixed microbial populations. Appl Environ Microbiol 56:1919-1925

Anthony JP, Fyfe L, Smith H (2005) Plant active components - a resource for antiparasitic agents? Trends Parasitol 21:7. https:// doi.org/10.1016/j.pt.2005.08.004

Barone CD, Zajac AM, Ferguson SM et al (2019) In vitro screening of 51 birdsfoot trefoil (Lotus corniculatus L.; Fabaceae) strains for anti-parasitic effects against Haemonchus contortus. Parasitology 146:828-836. https://doi.org/10.1017/S0031182018002214

Bianchi S, Kroslakova I, Janzon R et al (2015) Characterization of condensed tannins and carbohydrates in hot water bark extracts of European softwood species. Phytochemistry 120:53-61. https:// doi.org/10.1016/j.phytochem.2015.10.006

Bianchi S, Zikeli F, Vinciguerra V et al (2019) Characterization of Pinus nigra var. laricio [Maire] bark extracts at the analytical and pilot scale. Holzforschung 73:353-361. https://doi.org/10.1515/ hf-2018-0105

Bustin SA, Benes V, Garson JA et al (2009) The MIQE Guidelines: Minimum Information for Publication of Quantitative Real-Time PCR Experiments. Clin Chem 55:611-622. https://doi.org/10. 1373/clinchem.2008.112797

Campbell AT, Robertson LJ, Smith HV (1992) Viability of Cryptosporidium parvum oocysts: correlation of in vitro excystation with inclusion or exclusion of fluorogenic vital dyes. Appl Environ Microbiol 58:3488-3493

Carter BL, Stiff RE, Elwin K et al (2019) Health sequelae of human cryptosporidiosis - a 12-month prospective follow-up study. Eur J Clin Microbiol Infect Dis 38:1709-1717. https://doi.org/10.1007/ s10096-019-03603-1

Castañeda-Ramírez GS, Torres-Acosta JFJ, Sandoval-Castro CA et al (2017) Is there a negative association between the content of condensed tannins, total phenols, and total tannins of tropical plant extracts and in vitro anthelmintic activity against Haemonchus contortus eggs? Parasitol Res 116:3341-3348. https://doi.org/10. 1007/s00436-017-5650-4
Derbakova A, Keidāne D, Liepa L, Zolnere E (2016) The effect of sea buckthorn (Hippophae rhamnoides) extract on Cryptosporidium spp. invasion in calves. Res Rural Dev 1:140-143. https://doi.org/ 10.3168/jds.2009-2111

Desrues O, Fryganas C, Ropiak HM et al (2016a) Impact of chemical structure of flavanol monomers and condensed tannins on in vitro anthelmintic activity against bovine nematodes. Parasitology 143:444-454. https://doi.org/10.1017/S0031182015001912

Desrues O, Peña-Espinoza M, Hansen TVA et al (2016b) Anti-parasitic activity of pelleted sainfoin (Onobrychis viciifolia) against Ostertagia ostertagi and Cooperia oncophora in calves. Parasit Vectors 9:1-10. https://doi.org/10.1186/s13071-016-1617-z

Dhakal S, Meyling NV, Williams AR et al (2015) Efficacy of condensed tannins against larval Hymenolepis diminuta (Cestoda) in vitro and in the intermediate host Tenebrio molitor (Coleoptera) in vivo. Vet Parasitol 207:49-55. https://doi.org/10.1016/j.vetpar. 2014.11.006

Esteban-Ballesteros M, Sanchis J, Gutiérrez-Corbo C et al (2019) In vitro anthelmintic activity and safety of different plant species against the ovine gastrointestinal nematode Teladorsagia circumcincta. Res Vet Sci 123:153-158. https://doi.org/10.1016/j. rvsc.2019.01.004

Gaur S, Kuhlenschmidt TB, Kuhlenschmidt MS, Andrade JE (2018) Effect of oregano essential oil and carvacrol on Cryptosporidium parvum infectivity in HCT-8 cells. Parasitol Int 67:170-175. https://doi.org/10.1016/j.parint.2017.11.001

Grabber JH, Zeller WE, Mueller-Harvey I (2013) Acetone enhances the direct analysis of procyanidin- and prodelphinidin-based condensed tannins in lotus species by the butanol-HCl-iron assay. $\mathbf{J}$ Agric Food Chem 61:2669-2678. https://doi.org/10.1021/jf304 $158 \mathrm{~m}$

Graczyk TK, Grimes BH, Knight R et al (2003) Detection of Cryptosporidium parvum and Giardia lamblia carried by synanthropic flies by combined fluorescent in situ hybridization and a monoclonal antibody. Am J Trop Med Hyg 68:228-232. https://doi.org/ 10.4269/ajtmh.2003.68.228

Hamnes IS, Gjerde B, Robertson L (2006a) Prevalence of Giardia and Cryptosporidium in dairy calves in three areas of Norway. Vet Parasitol 140:204-216. https://doi.org/10.1016/j.vetpar.2006.03.024

Hamnes IS, Gjerde B, Robertson L et al (2006b) Prevalence of Cryptosporidium and Giardia in free-ranging wild cervids in Norway. Vet Parasitol 141:30-41. https://doi.org/10.1016/j.vetpar.2006. 05.004

Hernández-Bolio GI, García-Sosa K, Escalante-Erosa F et al (2018) Effects of polyphenol removal methods on the in vitro exsheathment inhibitory activity of Lysiloma latisiliquum extracts against Haemonchus contortus larvae. Nat Prod Res 32:508-513. https:// doi.org/10.1080/14786419.2017.1317774

Hoste H, Torres-Acosta JFJ, Sandoval-Castro CA et al (2015) Tannin containing legumes as a model for nutraceuticals against digestive parasites in livestock. Vet Parasitol 212:5-17. https://doi.org/10. 1016/j.vetpar.2015.06.026

Hur SN, Molan AL, Cha JO (2005) Effects of feeding condensed tannin-containing plants on natural coccidian infection in goats. Asian-Australasian J Anim Sci 18:1262-1266. https://doi.org/10. 5713/ajas.2005.1262

Innes EA, Chalmers RM, Wells B, Pawlowic MC (2020) A One Health Approach to Tackle Cryptosporidiosis. Trends Parasitol 36:290 303. https://doi.org/10.1016/j.pt.2019.12.016

Joachim A, Altreuther G, Bangoura B et al (2018) W A A V P guideline for evaluating the efficacy of anticoccidials in mammals (pigs, dogs, cattle, sheep). Vet Parasitol 253:102-119. https://doi.org/10. 1016/j.vetpar.2018.02.029

Keegan AR, Fanok S, Monis PT, Saint CP (2003) Cell CultureTaqman PCR Assay for Evaluation of Cryptosporidium parvum 
Disinfection. Appl Environ Microbiol 69:2505-2511. https://doi. org/10.1128/AEM.69.5.2505-2511.2003

Kim HC, Healey JM (2001) Effects of Pine Bark Extract Administered to Immunosuppressed Adult Mice Infected with Cryptosporidium parvum. Am J Chin Med 29:469-475. https://doi.org/10.1142/ S0192415X01000484

Klima- og miljødepartementet (2004) Forskrift om begrensning av forurensning (forurensningsforskriften). Klima- og miljødepartementet, Norway

Kosek M, Alcantara C, Lima AAM, Guerrant RL (2001) Cryptosporidiosis : an update. Lancet 1:262-269. https://doi.org/10. 1016/S1473-3099(01)00121-9

Lange H, Johansen OH, Vold L et al (2014) Second outbreak of infection with a rare Cryptosporidium parvum genotype in schoolchildren associated with contact with lambs/goat kids at a holiday farm in Norway. Epidemiol Infect 142:2105-2113. https://doi.org/ 10.1017/S0950268813003002

Matthews S, Mila I, Scalbert A, Donnelly DMX (1997) Extractable and non-extractable proanthocyanidins in barks. Phytochemistry 45:405-410. https://doi.org/10.1016/S0031-9422(96)00873-4

Molan AL (2014) Effect of purified condensed tannins from pine bark on larval motility, egg hatching and larval development of Teladorsagiacircumcincta and Trichostrongyluscolubriformis (Nematoda: Trichostrongylidae). Folia Parasitol (Praha) 61:371-376. https://doi.org/10.14411/fp.2014.036

Molan AL, Liu Z, De S (2009) Effect of pine bark (Pinusradiata) extracts on sporulation of coccidian oocysts. Folia Parasitol (Praha) 56:1-5

Morgan UM, Constantine CC, Forbes DA, Thompson RCA (1997) Differentiation between human and animal isolates of Cryptosporidium parvum using rDNA sequencing and direct PCR analysis. J Parasitol 83:825-830. https://doi.org/10.2307/3284275

Mueller-Harvey I, Bee G, Dohme-Meier F et al (2019) Benefits of condensed tannins in forage legumes fed to ruminants: importance of structure, concentration, and diet composition. Crop Sci 59:861-885. https://doi.org/10.2135/cropsci2017.06.0369

Novobilsky A, Mueller-Harvey I, Thamsborg SM (2011) Condensed tannins act against cattle nematodes. Vet Parasitol 182:213-220. https://doi.org/10.1016/j.vetpar.2011.06.003

Novobilsky A, Stringano E, Carbonero $\mathrm{CH}$ et al (2013) In vitro effects of extracts and purified tannins of sainfoin (Onobrychis viciifolia) against two cattle nematodes. Vet Parasitol 196:532-537. https:// doi.org/10.1016/j.vetpar.2013.03.024

Nygård K, Vold L, Robertson L, Lassen J (2003) Are domestic Cryptosporidium and Giardia infections in Norway underdiagnosed? In Norwegian. Tidskr Den nor Legeforening 123:3406-3409

Petersen HH, Enemark HL (2018) Viability Assessment of Cryptosporidium parvum Oocysts by Vital Dyes: Dry Mounts Overestimate the Number of "ghost" Oocysts. Foodborne Pathog Dis 15:141-144. https://doi.org/10.1089/fpd.2017.2348

Ramos V, Bocalandro C, Riquelme S et al (2013) Effect of the bench scale extraction conditions on Pinus radiata bark extract yield, antioxidant properties and composition. Maderas Cienc y Tecnol 15:31-44. https://doi.org/10.4067/S0718-221X2013005000003

Rimšelienė G, Vold L, Nygård K et al (2011) An outbreak of gastroenteritis among schoolchildren staying in a wildlife reserve: thorough investigation reveals Norway's largest cryptosporidiosis outbreak. Scand J Public Health 39:287-295. https://doi.org/10. $1177 / 1403494810396557$
Robertson L, Gjerde B, Forberg T, Haugejorden G (2006) A small outbreak of human cryptosporidiosis associated with calves at a dairy farm in Norway. Scand J Infect Dis 38:810-813. https://doi. org/10.1080/00365540600606457

Shahiduzzaman M, Dyachenko V, Khalafalla RE et al (2009) Effects of curcumin on Cryptosporidium parvum in vitro. Parasitol Res 105:1155-1161. https://doi.org/10.1007/s00436-009-1535-5

Slifko TR, Friedman D, Rose JB, Jakubowski W (1997) An in vitro method for detecting infections Cryptosporidium oocysts with cell culture. Appl Environ Microbiol 63:3669-3675

Smith H (2008) OIE listed diseases and other diseases of importance to international trade. In: Edwards S, Vallat B (eds) OIE Manual of Diagnostic Tests and Vaccines for Terrestrial Animals (mammals, birds and bees), 6th edn. OIE World organisation for animal health, Paris, pp 1192-1215

Spiegler V, Liebau E, Hensel A (2017) Medicinal plant extracts and plant-derived polyphenols with anthelmintic activity against intestinal nematodes. Nat Prod Rep 34:627-643. https://doi.org/10. 1039/c6np00126b

Sreter T, Szell Z, Varga I (1999) Attempted Chemoprophylaxis of Cryptosporidiosis in Chickens, Using Diclazuril, Toltrazuril, or Garlic Extract. J Parasitol 85:989-991. https://doi.org/10.2307/ 3285847

Teichmann K, Kuliberda M, Schatzmayr G et al (2012) In vitro determination of anticryptosporidial activity of phytogenic extracts and compounds. Parasitol Res 111:231-240. https://doi.org/10.1007/ s00436-012-2824-y

Teichmann K, Kuliberda M, Schatzmayr G et al (2016) In vitro inhibitory effects of plant-derived by-products against Cryptosporidium parvum. Parasite 23:8. https://doi.org/10.1051/parasite/2016050

The European Commission (2020) Commission regulation (EU) No $37 / 2010$ of 22 December 2009 on pharmacologically active substances and their classification regarding maximum residue limits in foodstuffs of animal origin. The European Commission, Brussels, Belgium

Upton SJ, Tilley M, Brillhart DB (1994) Comparative development of Cryptosporidium parvum (Apicomplexa) in 11 continuous host cell lines. FEMS Microbiol Lett 118:233-236. https://doi.org/10. 1111/j.1574-6968.1994.tb06833.x

US food and drug administration (2020) FDA Green Book. In: FDA. https://www.fda.gov/animal-veterinary/products/approved-animal-drug-products-green-book

Williams AR, Fryganas C, Ramsay A et al (2014) Direct anthelmintic effects of condensed tannins from diverse plant sources against Ascaris suum. PLoS ONE 9:16. https://doi.org/10.1371/journal. pone. 0097053

Woolsey ID, Blomstrand B, Øines Ø, Enemark HL (2019a) Assessment of differences between DNA content of cell-cultured and freely suspended oocysts of Cryptosporidium parvum and their suitability as DNA standards in qPCR. Parasit Vectors 12:17. https:// doi.org/10.1186/s13071-019-3851-7

Woolsey ID, Valente AH, Williams AR et al (2019b) Anti-protozoal activity of extracts from chicory (Cichorium intybus) against Cryptosporidium parvum in cell culture. Sci Rep 9:1-9. https:// doi.org/10.1038/s41598-019-56619-0

Publisher's note Springer Nature remains neutral with regard to jurisdictional claims in published maps and institutional affiliations. 